\title{
Тетяна Серьогіна
}

Дніпропетровський регіональний інститут державного управління Національної академії державного управління при Президентові України

\section{Розвиток системи публічних послуг у контексті цифровізації публічного управління}

У дослідженні розкрито невід’ємність тенденцій цифровізації суспільства від сучасної системи надання публічних послуг, що є одним із провідних елементів електронного уряду. Окрему увагу приділено перевагам, що надає його залучення, а також проблемним питанням, що виникають на вітчизняному грунті в умовах запровадження новітніх технологій. Запропоновано розглядати концепцію «Держава в смартфоні» крізь призму етапів становлення електронного уряду. Наголошено на необхідності врахування досвіду зарубіжних країн у розбудові системи надання публічних послуг у сучасних умовах.

Ключові слова: система публічних послуг, електронний уряд, цифровізація, адміністративна процедура, інформаиія

\section{Development of the public services system in the context of digitalization of public administration}

\section{Tetiana Serohina, Dnipropetrovsk Regional Institute for Public Administration National Academy for Public Administration under the President of Ukraine}

The study reveals the inseparability of the trends of digitalization of society from the modern system of public services, which is one of the leading elements of e-government. Particular attention is paid to the advantages of its involvement, as well as problematic issues that arise on domestic soil in the introduction of new technologies. It is proposed to consider the concept of "State in a smartphone" through the prism of the stages of formation of e-government. Emphasis is placed on the need to take into account the experience of foreign countries in developing a system of public services in modern conditions.

Keywords: public service system, e-government, digitalization, administrative procedure, information

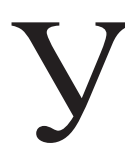

процесах цифрової революції трансформація системи надання публічних послуг посідає особливе місце. Переваги залучення в систему новітніх технологій $є$ очевидними, адже «електронна демократія не тільки висуває суспільству цілковито особливі вимоги, але й дає виняткові можливості, зокрема й вельми зручні для громадян, коли мова йде про надання громадянину публічних послуг» (Барциц, 2013).

Однією з беззаперечних переваг виступає зменшення кількості (як у абсолютному так і у відносному вимірах) адміністративних процедур, про що зазначають сучасні дослідники: «електронний уряд зменшує адміністративне навантаження. Він виключає дублювання однієї й тієї ж інформації, що надходить від окремих осіб та фірм і обмежує кількість процедур, пов'язаних із їі відбором» (Применение электронного правительства для формирования устойчивого и гибкого общества, 2018). Ще одним аргументом на користь залучення технологій виступає економія ресурсів, адже, як встановлено, цифрова операція обходиться органу публічної влади в 50 разів дешевше, ніж шляхом взаємодії при особистій зустрічі. Відтак, «функціонування електронного уряду містить великий потенціал для країн, не тільки в сенсі покращення організаційних і робочих процесів для підвищення ефективності надання державних послуг, але також і в питаннях залучення людей у ці процеси й забезпечення відповідальності» (Применение электронного правительства для формирования устойчивого и гибкого общества, 2018).

Проте в Україні, попри значні напрацювання в сфері електронного урядування, існує ціла низка перешкод для розвитку системи публічних послуг на сучасних засадах. Так, у сфері надання адміністративних послуг, згідно 3 даними, «лише в $11 \%$ 
ЦНАПах особа може здійснити попередній електронний запис, у $18 \%$ існує електронна черга, у всіх інших випадках для отримання адміністративної послуги особа повинна витратити значну кількість часу на знаходження у черзі» (Козаченко, 2018). Ще одним показником виступає доступ до Wi-Fi «у 2 \% ЦНАПах є вільний доступ до $\mathrm{Wi}-\mathrm{Fi}$, а це приблизно лише у 15 відділеннях по всій території України» (Козаченко, 2018).

Відтак, становлення електронного уряду в країні виступає найголовнішою передумовою становлення ефективної системи надання публічних послуг. Сучасні науковці виокремлюють п’ять основних етапів становлення електронного уряду:

1. «навчальний етап присутності держави в Мережі (emerging web presence), що характеризується наявністю офіційних урядових сайтів, які містять базову інформацію, що надається користувачам державою в односторонньому порядку;

2. посилення присутності держави в Мережі (enhanced web presence): інформація, яка надається стає більш динамічною, при цьому користувачі отримують більше можливостей для доступу до інформації, заповненню форм, зв'язку з державними органами;

3. на етапі інтерактивної присутності держави в Мережі (interactive web presence) здійснюється двосторонній обмін інформацією між користувачами й урядовими органами, з'являється більше можливостей по заповненню форм, деякі онлайн-сервіси, можливості відправки заяв онлайн;

4. присутність держави в Мережі на рівні трансакцій (transactional web presence): користувачі мають доступ до даних на основі своїх потреб, можуть відстежувати статус розгляду своєї заяви онлайн, існують різні трансакції, що здійснюються онлайн (сплата податків, сплата реєстраційного збору й митних зборів);

5. повністю інтегрована присутність держави в Мережі (seamless web presence) характеризується завершеною повною інтеграцією всіх державних інтернет-ресурсів в межах єдиного порталу» (Государственные услуги онлайн: от предоставления информации к электронному правительству). 118
Похідним від електронного уряду виступає проголошена концепція «Держава в смартфоні». Особливі очікування в модернізації системи надання публічних послуг при цьому покладаються на можливості мобільного зв'язку, що викладено в концепції «Держава в смартфоні». Це пов'язано 3 загальносвітовою тенденцією до швидкого збільшення масштабів використання мобільних пристроїв (у 2017 р. кількість абонентських договорів на надання послуг мобільного зв'язку складала 103,5 на 100 мешканців, оскільки одна людина може складати більше одного договору). Це створює потенціал для надання мобільних державних послуг в якості різновиду послуг електронного уряду. На особливу увагу заслуговує та обставина, що мобільний зв'язок дозволяє державам охопити найбільш вразливі верстви населення (Применение электронного правительства для формирования устойчивого и гибкого общества, 2018).

Важливо враховувати, що складнощі виникають не тільки на шляху становлення електронного урядування, але й у процесі запровадження цифрових технологій у систему публічних послуг. Прикладом може виступити такий елемент електронної демократії, як «електронні картки». Основним їх призначенням виступає засвідчення прав громадянина на отримання певної послуги. Проте досвід введення універсальних карт продемонстрував не тільки позивні сторони. Відтак, у Великій Британії й Німеччині відмовилися від їх застосування через негативні наслідки від єдиного засобу зберігання всієї інформації про особу.

Цілком зрозуміло, що в процесі втілення практики електронного уряду постають різноманітні перешкоди, зокрема, можливість доступу до Інтернет-мережі. Цікавим рішенням при цьому може виступити досвід Сполучених Штатів Америки зі Службою підтримки по СМС для молодих і майбутніх мам (Text4Baby). Програма відправляє молодим і майбутнім мамам щотижнево інформацію, яким чином дбати про себе й свою дитину під час вагітності й у перший рік життя. Результати показують високий рівень задоволення службою, при цьому дозволяють розширити знання про здоров'я, а та- 
кож сприяють тому, що мами більш активно взаємодіють 3 установами охорони здоров'я, а також виконують необхідні призначення. У цьому проекті брали участь більше 700 партнерів, це є гарним прикладом державно-громадської взаємодії (Применение электронного правительства для формирования устойчивого и гибкого общества, 2018).

Отже, з огляду на невід'ємність цифровізації від процесів трансформації системи надання публічних послуг, важливо окреслити коло переваг та викликів при цьому. В Україні, попри такі очевидні переваги, як зменшення адміністративного навантаження й суттєва економія ресурсів, існує ціла низка проблемних питань більшою мірою організаційно-технічного характеру. Адекватною відповіддю на виклики, що виникають, виступає врахування світового досвіду в становленні сучасної системи надання публічних послуг як одного з елементів електронного уряду. У становленні останнього виокремлюють п'ять основних етапів - від присутності держави в Мережі, що характеризується наявністю офіційних урядових сайтів, які містять базову інформацію, що надається користувачам державою в односторонньому порядку, до повної інтеграції всіх державних інтернет-ресурсів у межах єдиного порталу. Саме в межах п'ятого етапу слід розглядати Концепцію «Держави в смартфоні», для реалізації якої існує ціла низка передумов, зокрема, швидке збільшення масштабів використання мобільних пристроїв.

\section{БІБЛІОГРАФІЧНІ ПОСИЛАННЯ}

Барциц, И. (2013). Понятие «Публичная услуга» в контексте Федерального закона № 210-Ф3 «Об организации предоставления государственных и муниципальных услуг» и вне его. Государство и право, $10,40-51$.

Белорусский институт реформы и трансформации публичного администрирования. Государственные услуги онлайн: от предоставления информации к электронному правительству. Аналитическая записка. Восстановлено с http://sympa-by.eu/sites/default/files/library/gosudarstvennye_uslugi_onlain_ot_predostavleniya_ informacii_k_elektronnomu_pravitelstvu_.pdf.

Козаченко, Ю. (2018). Запровадження критеріїв оцінювання якості надання публічних послуг. Інвестииіï: практика та досвід, 16, 82-86.

Применение электронного правительства для формирования устойчивого и гибкого общества: Исследование ООН: Электронное правительство. (2018). Відновлено 3 https://publicadministration.un.org/egovkb/ Portals/egovkb/Documents/un/2018-Survey/E-Government\%20Survey\%202018_Russian.pdf. 